\title{
極超音速希薄流における並進。回転エネルギーの微視的状態 :
}

\section{気体分子衝突モデルの影響}

Microscopic State of Translational and Rotational Energy in Hypersonic Rarefied Gas Flow :

Effects of Gas-gas Collision model

\author{
$\bigcirc$ 正 坪井伸幸 (宇宙研) 正 松本洋一郎 (東京大学)
}

Nobuyuki TSUBOI, ISAS, 3-1-1, Hikinodai, Sagamihara, Kanagawa 229-8510

Yoichiro MATSUMOTO, The University of Tokyo, 7-3-1, Hongo, Bunkyo-ku, Tokyo 113-8656

\begin{abstract}
A DSMC (direct simulation Monte Carlo) simulation using Dynamic Molecular Collision (DMC) model based on Molecular Dynamics (MD) calculation is applied for solving the two-dimensional nonequilibrium hypersonic rarefied flow over a flat plate with angle of leading edge. Numerical results show that nonequilibrium between translational and rotational temperature is obtained behind the leading edge over the plate. Translational and rotational energy distributions in the nonequilibrium flow show a typical distribution which is significantly different from the Maxwell-Boltzmann distribution, and reveal a transition process from the nonequilibrium state to the equilibrium state.
\end{abstract}

Key Words: Rarefied Gas Flow, Hypersonic Flow, Numerical Analysis, Nonequilibrium Flow

\section{1 はじめに}

近年，国内外で宇宙往還機及び惑星探査機の開発が活発に推 進されているが, その空力における重要な課題の 1 つとして, 再突入時の衝撃波／境界層干涉がある。その代表的な現象の- つとして，鋭い前縁を有する平板近傍で生じる粘性干涉が举げ られるが, Rarefaction parameter $\bar{V}>0.15$ であるような, 衝 慗波と境界層が融合する領域におうける流れ場の構造及び並進温 度と回転温度の非平衡現象はまだ十分に解明されていない。

本論文では，実験結果とDSMC 計算結果のより詳細な比較 を実施する。さらに, 衝突モデルとして Larsen-Borgnakke(LB) モデル [1] と Dynamic Molecular Collision(DMC) モデル [2] をそれぞれを使用した場合のDSMC 計算結果を比較する。そ の際，巨視的な状態量としての温度，圧力等，そして微視的な 状態量である並進エネルギー及び回転エネルギー分布の比較を 行う。そして特に後者に関して, 衝突モデルが微視的な状態量 に与える影響を定量的に把握する。

\section{2 数値計算法}

本研究で使用した 2 次元 DSMC 法の衝突モデルは，分子動 力学法によって構築されたデータを基にしている。また，分子 衝突頻度の計算には, Null-Collision 法を使用している。壁面 境界条件は拡散反射を適用した。LB モデルにおける非弾性衝 突確率 $\phi$ は，0(No.2)，0.5(No.3) 及び 1.0(No.4) を使用した。

\section{3 結鼠及び考察}

計算条件は, Lengrand らが実験で実施した条件 [3] を元に しており, $M_{\infty}=20.2, R e_{\infty}=566, K n_{\infty}=0.047$ である $(L=0.05 \mathrm{~m}$ 基準)。詳細な計算条件は講演論文を参照されたい。 微視的な見地から，LB モデルと DMC モデルの比較を示す。 図 1 に $X / L=0.5$ に扔ける並進エネルギー分布を示寸。前縁近 傍では, どの結果も Maxwell-Boltzmann (MB) 分布と大きく 異なっていることが分かる。しかし，LB モデルの非弾性衝突 確率 $\phi$ が 0 では並進エネルギーは MB 分布に近く， $\phi=1$ では $\mathrm{MB}$ 分布と大きく異なっていることが分かる。DMC モデルは
LB モデル $(\phi=0.5)$ と大きな違いは見られない。また，回転エ ネルギー分布の場合は，並進エネルギーの場合とは逆に，LB モ デルの非弾性衝突確率 $\phi$ が 1 では回転エネルギーは MB 分布に 近く, $\phi=0$ では MB 分布と大きく異なっている。DMC モデ ルは LB モデル $(\phi=0.5,1.0)$ の間の分布を示している。DMC モデルと LB モデル $(\phi=0.5)$ の回転温度はほとんど違いがな いにもかかわらず，回転エネルギー分布は大きな違いが現れて いる。DMC モデルは非弾性衝突確率の温度依存性は MD 計算 のデータベース中に組み込まれている。そして，本計算条件だ けでなく 1 次元垂直衝撃波に関しても, 非弾性衝突確率の值に 依存せずに非平衡な流れ場を解析できることが示されている点 [2] で，LB モデルよりも物理的根拠がありかつ，十分に優位性 があることが本結果から示された。
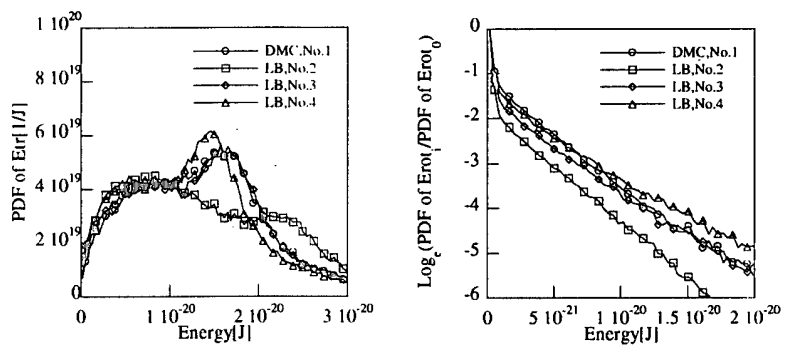

Fig. 1: Energy distributions on the plate at $X / L=0.5$ (left : translational energy; right : rotational energy).

\section{参萔文献}

[1] Borgnakke, C., Larsen, P.S., J. of Comp. Phys., 18, No.3 (1975), 405-420.

[2] Tokumasu, T. and Matsumoto Y., Phys. Fluids, Vol. 11, No.7(1999), 1907-1920.

[3] Lengrand, J.C. et al., 18th Int. Symp. on Rarefied Gas Dynamics (1992), 276-284. 